Tropical Journal of Pharmaceutical Research July 2019; 18 (7): 1455-1460

ISSN: $1596-5996$ (print); 1596-9827 (electronic)

(C) Pharmacotherapy Group, Faculty of Pharmacy, University of Benin, Benin City, 300001 Nigeria.

\title{
Sparteine exerts anticancer effect on human cervical cancer cells via induction of apoptosis, G0/G1 cell cycle arrest and inhibition of VEGFR2 signalling pathway
}

\author{
Songnian Liang ${ }^{1 *}$, Linlin Liü ${ }^{2}$ \\ ${ }^{1}$ Department of Radiology, The First Hospital of China Medical University, ${ }^{2}$ Mental health Center for Student, China Medical \\ University, Shenyang, Liaoning110001, China \\ *For correspondence: Email: sophia.hill20@yahoo.com; Tel/Fax: 0086-024-83282730
}

Sent for review: 28 January 2019

Revised accepted: 20 June 2019

\begin{abstract}
Purpose: To investigate the anticancer effects of sparteine against human cervical cancer. Methods: Cell viability was determined by CCK8 assay, while 4', 6-diamidino-2-phenylindole (DAPI) staining was used for determination of apoptosis. Cell cycle analysis was done with flow cytometry, while cell invasion was monitored using Transwell invasion assays. Protein expressions were determined using Western blotting.

Results: The results revealed that sparteine inhibited the viability of cervical cancer cells with halfmaximal inhibitory concentration (I $\left.I_{50}\right)$ ranging from 10 to $25 \mu M$. Sparteine exerted more profound antiproliferative effects on DoTc2 cells, with IC $C_{50}$ of $10 \mu \mathrm{M}$. However, minimal cytotoxicity was observed in normal cervical cells, as evident from the $I C_{50}$ of $80 \mu \mathrm{M}$. Sparteine triggered the generation of ROS and apoptotic cell death in DoTc2 cells. The induction of apoptosis was accompanied by upregulation of Bax expression and downregulation of Bcl-2 expression. Sparteine caused arrest of DoTc2 cells at the $G_{0} / G_{1}$ phase of the cell cycle, and suppressed the expressions of cyclin A and cyclin B1. Transwell assay data showed that sparteine decreased the invasion ability of DoTc2 cells. Sparteine also inhibited the phosphorylation of VGFR2 in a concentration-dependent manner.

Conclusion: Sparteine exhibits significant anticancer activity and may prove beneficial in cervical cancer chemotherapy.
\end{abstract}

Keywords: Cervical cancer, Apoptosis, Cell cycle arrest, Sparteine

\begin{abstract}
This is an Open Access article that uses a fund-ing model which does not charge readers or their institutions for access and distributed under the terms of the Creative Commons Attribution License (http://creativecommons.org/licenses/by/4.0) and the Budapest Open Access Initiative (http://www.budapestopenaccessinitiative.org/read), which permit unrestricted use, distribution, and reproduction in any medium, provided the original work is properly credited.

Tropical Journal of Pharmaceutical Research is indexed by Science Citation Index (SciSearch), Scopus, International Pharmaceutical Abstract, Chemical Abstracts, Embase, Index Copernicus, EBSCO, African Index Medicus, JournalSeek, Journal Citation Reports/Science Edition, Directory of Open Access Journals (DOAJ), African Journal Online, Bioline International, Open-J-Gate and Pharmacy Abstracts
\end{abstract}

\section{INTRODUCTION}

Cervical cancer imposes huge disease burden on all nations across the globe. Approximately, 260,000 cervical cancer mortalities and 530,000 new cases of cervical cancer were reported in 2012 alone [1]. Owning to disproportionate incidence of cervical cancer in low and high- income nations, it is often referred to as the 'disease of disparity' [2]. Cervical cancer is ranked the fourth major type of cancer in the world [3]. The treatments for cervical cancer involve radical hysterectomy, chemotherapy and/or radiotherapy [4]. 
However, the currently available chemotherapeutic agents have adverse effects on the quality of life of patients [5]. This has fuelled the search for novel and effective anticancer agents for combating this disease. One of the major concerns of researchers is identification of natural anticancer principles for the development of chemotherapy for cervical cancer [6]. Among natural products, alkaloids constitute a large and diverse group of metabolites in the plant kingdom. The potential of alkaloids as anticancer agents has increased tremendously with the discovery of the alkaloidal anticancer agents vinblastine and vincristine [7].

Sparteine is an important alkaloid isolated from Lupinus species. It belongs to the group of quinolizidine alkaloids and has been reported to exhibit analgesic activity [8]. Nonetheless, there is no single report in the literature on the anticancer activity of sparteine. Therefore, this study was undertaken to investigate the anticancer effects of sparteine against a panel of human cervical cancer cell lines and one normal cell line. Moreover, the effect of sparteine on the therapeutically important VEGFR2 pathway was investigated [9].

\section{EXPERIMENTAL}

\section{Determination of cell viability}

CCK-8 assay was used for the determination of cell viability of DoTc2 cervical cancer cells. Transfected DoTc2 cells were seeded in 96-well plates and subjected to treatment with varied concentrations of sparteine at $37{ }^{\circ} \mathrm{C}$ for $24 \mathrm{~h}$. Thereafter, $10 \mu \mathrm{L}$ of CCK-8 reagent was added to the cell culture and incubated for $2 \mathrm{~h}$ at $37{ }^{\circ} \mathrm{C}$ in a humidified atmosphere containing $5 \% \mathrm{CO}_{2}$ and $95 \% \mathrm{O}_{2}$. Optical density was read at 450 $\mathrm{nm}$ in a microplate reader, as an index of cell viability.

\section{DAPI staining assay}

Cervical cancer DoTc2 cells $\left(0.6 \times 10^{6}\right)$ were cultured in 6-well plates. They were treated with varied concentrations of sparteine, and incubated for $24 \mathrm{~h}$ at $37{ }^{\circ} \mathrm{C}$. As the cells sloughed off, $10 \mu \mathrm{L}$ cell culture was put onto a glass slide and subjected to staining with DAPI. The slides were covered with a cover slip and examined under a fluorescent microscope.

\section{Transwell assay}

The invasion abilities of the DoTc2 cells were determined with Transwell chamber invasion assay. The cells $\left(1 \times 10^{4}\right)$ were seeded in upper chamber of the transwell $(8 \mu \mathrm{m}$ pore size polycarbonate filters). This was followed by the incubation of the chambers at $37^{\circ} \mathrm{C}$ for $24 \mathrm{~h}$. The inserts were coated with extracellular matrix gel $(50 \mu \mathrm{L})(\mathrm{ECM}$, Sigma, USA). Swabbing was performed to remove the non-invaded cells from the upper surface. However, the invaded cells on the lower surface were fixed with methanol and then stained with crystal violet $(0.5 \%)$ for about $50 \mathrm{~min}$. The cells were then washed with PBS, and finally counted under the light microscope (5 fields).

\section{Cell cycle analysis}

DoTc2 cells were treated with varied concentrations of sparteine and incubated for 24 at $37{ }^{\circ} \mathrm{C}$. Thereafter, the cells were washed with phosphate buffered saline (PBS), and the KGN cells were stained with propidium lodide $(\mathrm{PI})$. The distribution of cells in cell cycle phases was assessed using FACS flow cytometer.

\section{Cell invasion assay}

\section{Western blot analysis}

Sparteine-treated DoTc2 cells were harvested using centrifugation and then lysed in lysis buffer containing protease inhibitor. About $45 \mu \mathrm{g}$ of protein from each sample was subjected to separation on $10 \%$ SDS-PAGE. The protein bands were transferred to polyvinylidene difluoride (PVDF) membrane, and the membrane was then blocked with fat-free milk at room temperature for $1 \mathrm{~h}$. The membrane was treated with appropriate primary antibodies at $4{ }^{\circ} \mathrm{C}$ overnight, and was subsequently incubated with secondary antibody. Finally, the signals were detected using Odyssey Infrared Imaging System (LI-COR, USA). Actin was used as control for normalisation.

\section{Statistical analysis}

All assays were performed in triplicate and the values are shown as mean \pm standard deviation $(\mathrm{SD}, \mathrm{n}=3)$. Student's $t$-test was employed for statistical analysis using GraphPad Prism 7 software. Values of $p<0.05$ were considered statistically significant.

\section{RESULTS}

\section{Sparteine exerted growth inhibitory effects on} cervical cancer cells

The effects of sparteine were evaluated against a panel of four cervical cancer cell lines (CaSki, DoTc2, SiHA, C-33A) and one normal cell line 
(HCvEpC) (Figure $1 \mathrm{~A})$. The results indicated that sparteine suppressed the proliferation of all the cervical cancer cells, with $\mathrm{IC}_{50}$ values ranging from 10 to $25 \mu \mathrm{M}$ (Table 1). It was observed that sparteine exerted more significant anticancer effects on the DoTc2 cells, with an $\mathrm{IC}_{50}$ of $10 \mu \mathrm{M}$ (Figure $1 \mathrm{~B}$ ). Evaluation of the anti-proliferative effects of sparteine on normal HCvEpC cells showed that sparteine exerted minimal growth inhibitory effects on these cells $\left(\mathrm{IC}_{50}=80 \mu \mathrm{M}\right)$. The growth inhibitory effects of sparteine on the cervical cancer cells exhibited a dose-dependent pattern.

Table 1: Anticancer effect $\left(\mathrm{IC}_{50}\right)$ of sparteine on cervical cancer and normal cell lines

\begin{tabular}{lc}
\hline Cell line & $\mathbf{I C}_{50}(\boldsymbol{\mu M})$ \\
\hline DoTc2 & 10 \\
SiHa & 25 \\
HeLa & 7.5 \\
C33A & 25 \\
HCvEpC & 80 \\
\hline
\end{tabular}
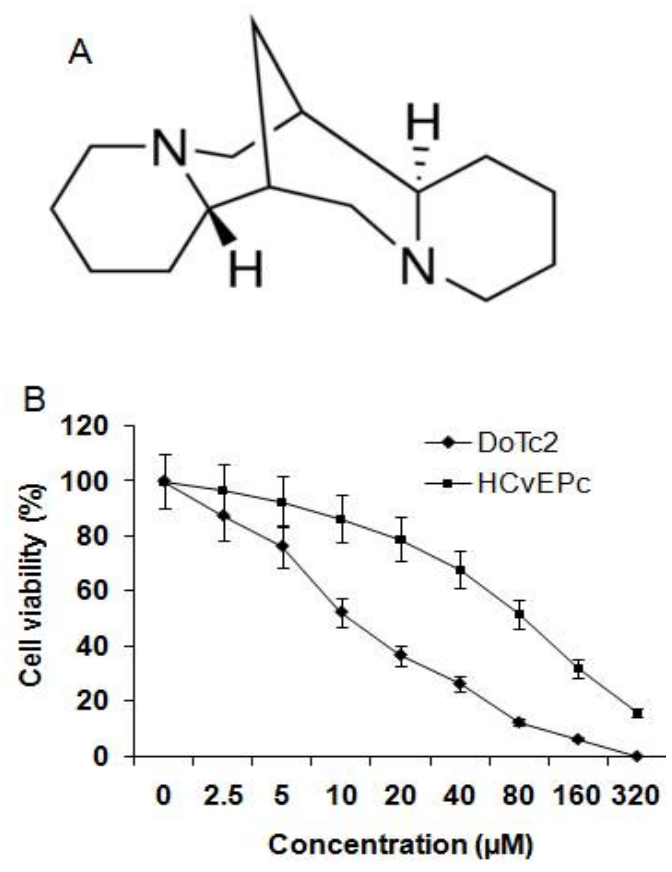

Figure 1: (A) Chemical structure of sparteine; (B) CCK-8 assay showing the effect of sparteine on the viability of cervical cancer DoTc2 and normal HCvEPc cells. Data are expressed as mean $\pm \operatorname{SD}(n=3)$. ${ }^{*} p<$ 0.05)

\section{Sparteine promoted generation of ROS in DoTc2 cells}

The effects of different concentrations of sparteine on ROS levels in DoTc2 cells were investigated. It was revealed that sparteine caused dose-dependent increases in the ROS levels of the DoTc2 cells (Figure 2). The ROS level increased to $205 \%$, relative to $100 \%$ in control. Moreover, the sparteine-induced increases in ROS levels were concentrationdependent.

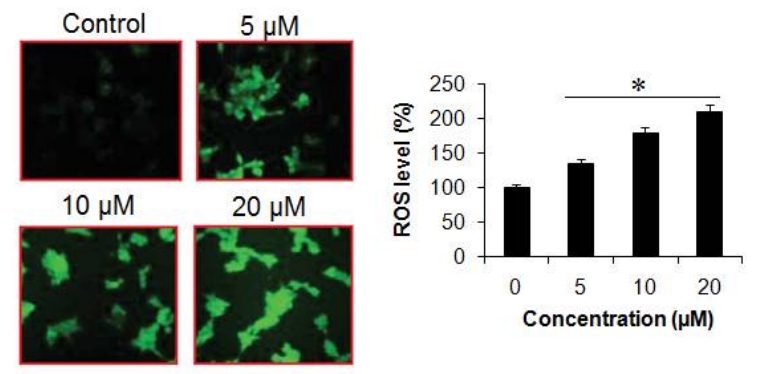

Figure 2: Effect of sparteine on ROS levels in DoTc2 cells at indicated concentrations. Data are expressed as mean $\left.\pm \operatorname{SD}(\mathrm{n}=3) ;{ }^{*} p<0.05\right)$

\section{Sparteine caused apoptotic cell death of DoTc2 cells}

To ascertain if sparteine inhibited DoTc2 cell proliferation via induction of apoptotic cell death, DAPI staining of the sparteine-treated DoTc2 cells was performed. The results showed that sparteine caused nuclear fragmentation in DoTc2 cells in a dose-dependent manner (Figure $3 \mathrm{~A}$ ). These alterations in the nuclear morphology of the DoTc2 cells were characteristic of apoptosis. Therefore, western blot analysis was performed to determine the expressions of $\mathrm{Bax}$ and $\mathrm{Bcl}-2$ (Figure $3 \mathrm{~B}$ ). The expression of Bax was found to increase while as that of bcl-2 decreased in the DoTc2 cells, upon sparteine treatment.

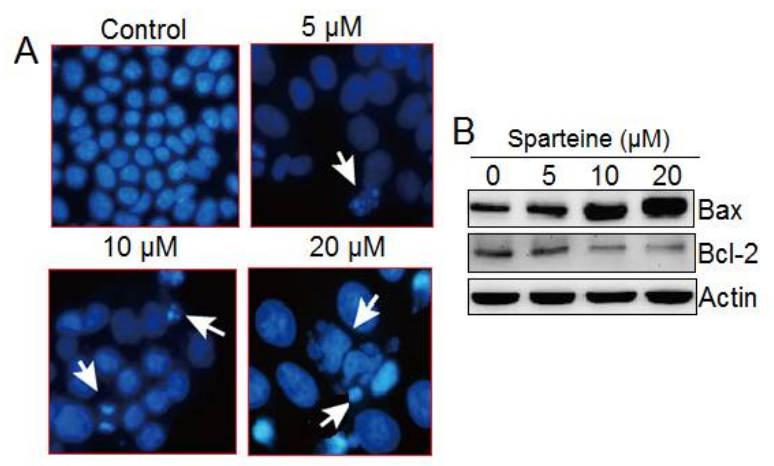

Figure 3: (A) DAPI staining showing induction of apoptosis in the sparteine treated DoTc2 cells (Arrows depict apoptotic cells) (B) Effect of sparteine on the expressions of Bax and $\mathrm{Bcl}-2$ in DoTc2 cells at indicated concentrations. The experiments were performed in triplicate

\section{Sparteine caused arrest of DoTc2 cells at $\mathrm{G}_{0} / \mathrm{G}_{1}$ checkpoint}

The effect of sparteine on the distribution of the DoTc2 cells in different cell cycle phases was also studied. The results indicated that sparteine 
treatment caused a significant increase in the $\mathrm{G}_{0} / \mathrm{G}_{1}$ phase of the cell cycle, which indicated $\mathrm{G}_{0} / \mathrm{G}_{1}$ arrest (Figure $4 \mathrm{~A}$ ). This was also accompanied by downregulation of cyclin $A$ and cyclin B1 expressions in a dose-dependent manner (Figure 4 B).
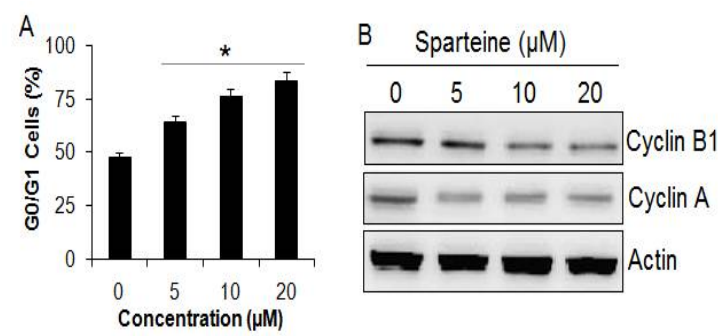

Figure 4: (A) Flow cytometric analysis showing that sparteine induced $\mathrm{G} 0 / \mathrm{G} 1$ arrest of the DoTc2 cells. (B) Effect of sparteine on the expressions of cyclin A and cyclin B1. Data are expressed as mean $\left.\pm \mathrm{SD}(\mathrm{n}=3) .{ }^{*} p<0.05\right)$

\section{Sparteine inhibited invasion of the DoTc2 cells}

Transwell assay was used to monitor the effect of $10 \mu \mathrm{M}\left(\mathrm{IC}_{50}\right)$ of sparteine on the invasion of the DoTc2 cervical cancer cells. The results showed that sparteine caused significant decrease in the invasion of the DoTc2 cells (Figure 5). Invasion of DoTc2 cervical cancer cells decreased to $38 \%$, when compared to 100 $\%$ in untreated control.
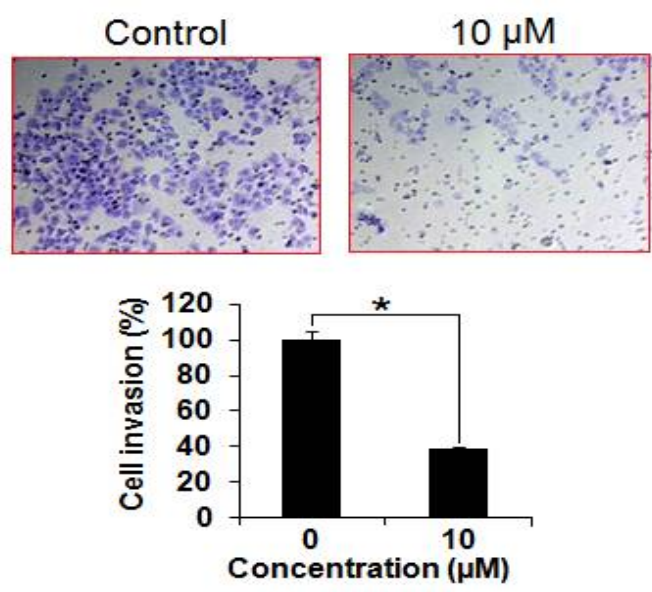

Figure 5: Effect of sparteine at $\mathrm{IC}_{50}$ on invasion of DoTc2 cells as depicted by transwell assay. Data are expressed as mean $\pm \operatorname{SD}(\mathrm{n}=3)$. $\left.{ }^{*} p<0.05\right)$

\section{Sparteine deactivated VEGFR2 pathway in DoTc2 cells}

The effect of sparteine was also investigated on the phosphorylation status of VEGFR2 in the DoTc2 cells (Figure 6). The results showed that the phosphorylation of VEGFR2 cells decreased concentration-dependently upon treatment with sparteine.

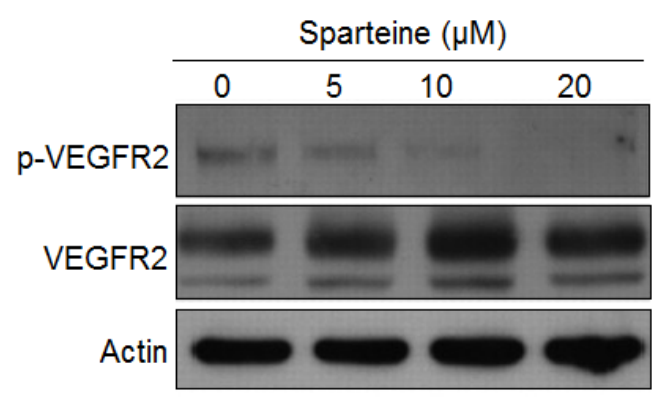

Figure 6: Effect of sparteine on the phosphorylation of $p$-VEGFR as depicted by western blot analysis. Experiments were performed in triplicate

\section{DISCUSSION}

Owing to drawbacks in cervical cancer chemotherapy, the development of new treatment strategies is of utmost priority for cancer researchers across the globe. Huge research efforts are regularly devoted to exploring effective treatments, as well as minimising the toxicities of the identified drugs [10]. Many of the anticancer drugs exhibit narrow therapeutic windows because of their low selectivity against cancer cells. Another goal of the researchers is to develop drugs that selectively target cancer cells or reduce their malignancy without any effect on normal cells [11].

One of the approaches is to explore chemical scaffolds isolated from terrestrial plants [12]. In the present study, the anticancer effect of the alkaloid sparteine against a panel of cervical cancer cells, was investigated. The results showed that sparteine selectively killed the cervical cancer cells, with greater profound effects on the DoTc2 cells. These observations are also supported by other studies carried on the quinolizidine alkaloids. For example, quinolizidine alkaloids from Sophora flavescens have been shown to inhibit the growth of cancer cells [13]. Studies have shown that many of the plant-derived alkaloids increase the generation of ROS in cancer cells [14]. For instance, it has been reported that the plant derived alkaloid berberine induced accretion of ROS in prostate cancer cells [15].

The effect of sparteine on ROS levels in the DoTc2 cells was also studied. Interestingly, it was revealed that sparteine caused accretion of significant amounts of ROS in DoTc2 cells. 
Studies have shown that ROS generation is linked to induction of apoptosis in cancer cells [16]. Indeed, DAPI staining of the sparteinetreated DoTc2 cervical cancer cells revealed that sparteine caused nuclear fragmentation of the DoTc2 cells. The apoptosis was further confirmed with the expression patterns of $\mathrm{Bax}$ and $\mathrm{Bcl}-2$ in the DoTc2 cells. It is known that Bax and $\mathrm{Bcl}-2$ are important biomarker proteins of apoptosis [17]. The results showed that sparteine upregulated Bax and downregulated Bcl-2. Previous studies have shown that the alkaloid sanguinarine induced apoptosis in breast cancer cells [18]. Alkaloids have also been reported to cause cell cycle arrest in cancer cells [19]. Neferine, an alkaloid, has been shown to cause cell cycle arrest in lung cancer cells [19]. In the present study, it was found that sparteine caused arrest of the DoTc2 cells in the $G_{0} / G_{1}$ phase of the cell cycle. Sparteine also inhibited invasion of the DoTc2 cells, indicating its anti-metastatic potential. Vascular endothelial growth factor-2 (VGFR2) is an important therapeutic target for cancer treatment [20]. The results obtained in this study showed that sparteine inhibited the phosphorylation of VGFR2. This is suggestive of the anti-cancer potential of sparteine.

\section{CONCLUSION}

The findings of this study show that sparteine exerts growth-inhibitory effects on DoTc2 cells via $R O S$-mediated apoptosis and $\mathrm{G}_{0} / \mathrm{G}_{1}$ arrest. It also suppresses the invasion of DoTc2 cells via inhibition of VGFR2 phosphorylation. Therefore, sparteine is a potential lead molecule for the development of cervical cancer chemotherapy.

\section{DECLARATIONS}

\section{Conflict of interest}

No conflict of interest is associated with this work.

\section{Contribution of authors}

We declare that this work was done by the authors named in this article and all liabilities pertaining to claims relating to the content of this article will be borne by the authors.

\section{Open Access}

This is an Open Access article that uses a funding model which does not charge readers or their institutions for access and distributed under the terms of the Creative Commons Attribution License (http://creativecommons.org/licenses/by/
4.0) and the Budapest Open Access Initiative (http://www.budapestopenaccessinitiative.org/rea d), which permit unrestricted use, distribution, and reproduction in any medium, provided the original work is properly credited.

\section{REFERENCES}

1. Schiffman M. Cervical cancer screening: epidemiology as the necessary but not sufficient basis of public health practice. Prev Med 2017; 8: 3-6.

2. Arbyn M, Castle PE. Offering self-sampling kits for HPV testing to reach women who do not attend in the regular cervical cancer screening program. Cancer Epidemiol Biomarkers Prev 2015; 1: 1414-1417.

3. Di Felice E, Caroli S, Paterlini L, Campari C, Prandi S, Rossi PG. Cervical cancer epidemiology in foreign women in Northern Italy: role of human papillomavirus prevalence in country of origin. Euron JCancer Prev 2015; 24(3): 223-230.

4. Motoki Y, Mizushima S, Taguri M, Takahashi K, Asano R, Kato $H$, Asai-Sato $M$, Katayama $K$, Okamoto $N$, Hirahara $F$, et al. Increasing trends in cervical cancer mortality among young Japanese women below the age of 50 years: an analysis using the Kanagawa population-based Cancer Registry, 1975-2012. Cancer Epidemiol 2015; 39(5): 700-706.

5. Muñoz $N$, Bosch $F X$, De Sanjosé $S$, Herrero $R$, Castellsagué $X$, Shah KV, Snijders PJ, Meijer CJ. Epidemiologic classification of human papillomavirus types associated with cervical cancer. $N$ Engl $J$ Med 2003; 348(6): 518-527.

6. Felice MR, Giuffre L, El LA, Hafidi M, Criseo G, Romeo $O$, Scordino $F$. Looking for new antifungal drugs from flavonoids: impact of the genetic diversity of Candida albicans on the in-vitro response. Curr Med Chem 2017; 21: 2-6.

7. Owellen RJ, Owens Jr AH, Donigian DW. The binding of vincristine, vinblastine and colchicine to tubulin. Biochem. Biophys Res Commun 1972; 47(4):685-691.

8. De Pinto MC, Barceló AR. Superoxide anion scavenger properties of sparteine, a quinolizidine alkaloid from Lupinus. Biochem Biophys Res Commun 1997; 150(12): 5-8.

9. Shi L, Zhang S, Wu H, Zhang L, Dai X, Hu J, Xue J, Liu $T$, Liang $Y, W u$ G. MiR-200c increases the radiosensitivity of non-small-cell lung cancer cell line A549 by targeting VEGF-VEGFR2 pathway. PloS One 2013; 30; 8(10):e78344.

10. Piver MS, Rutledge F, Smith JP. Five classes of extended hysterectomy for women with cervical cancer. Obstetrics Gynecol 1974; 44(2):265-272.

11. Rates SM. Plants as source of drugs. Toxicon. 2001; 39(5): 603-613.

12. Cragg GM, Newman DJ. Plants as a source of anticancer agents. J Ethnopharmacol 2005; 100(1-2):72-9.

13. Lin Z, Huang CF, Liu XS, Jiang J. In Vitro Anti-Tumour Activities of Quinolizidine Alkaloids Derived from

Trop J Pharm Res, July 2019; 18(7): 1459 
Sophora Flavescens Ait. Basic Clin Pharmacol Toxicol 2011;108(5):304-9.

14. Efferth $T$, Giaisi M, Merling A, Krammer PH, Li-Weber M. Artesunate induces ROS-mediated apoptosis in doxorubicin-resistant T leukemia cells. PLoS One. 2007; 2(8):e693.

15. Meeran SM, Katiyar S, Katiyar SK. Berberine-induced apoptosis in human prostate cancer cells is initiated by reactive oxygen species generation. Toxicol App Pharmacol 2008; 229(1):33-43.

16. Simon HU, Haj-Yehia A, Levi-Schaffer F. Role of reactive oxygen species (ROS) in apoptosis induction. Apoptosis. 2000; 5(5): 415-418.

17. Miyashita T, Krajewski S, Krajewska M, Wang HG, Lin HK, Liebermann DA, Hoffman B, Reed JC. Tumor suppressor $p 53$ is a regulator of bcl-2 and bax gene expression in vitro and in vivo. Oncogene. 1994;9(6):1799-1805.

18. Choi WY, Kim GY, Lee WH, Choi YH. Sanguinarine, a benzophenanthridine alkaloid, induces apoptosis in MDA-MB-231 human breast carcinoma cells through a reactive oxygen species-mediated mitochondrial pathway. Chemotherapy 2008; 54(4): 279-287.

19. Poornima P, Weng CF, Padma VV. Neferine, an alkaloid from lotus seed embryo, inhibits human lung cancer cell growth by MAPK activation and cell cycle arrest. Biofactors 2014; 40(1): 121-131.

20. Choueiri TK, Vaishampayan U, Rosenberg JE, Logan TF, Harzstark AL, Bukowski RM, Rini BI, Srinivas S, Stein $M N$, Adams LM, et al., Phase II and biomarker study of the dual MET/VEGFR2 inhibitor foretinib in patients with papillary renal cell carcinoma. J Clin Oncol 2013; 31(2):181. 